\title{
Hjerneinfarkt ved åpent foramen ovale
}

\begin{abstract}
BAKGRUNN Gjeldende retningslinjer for behandling av hjerneinfarkt som antas å skyldes åpent foramen ovale er ikke godt vitenskapelig dokumentert. I denne artikkelen presenterer vi en ung pasient med denne problemstillingen og gir samtidig en generell oversikt over forekomst, anbefalt utredning og indikasjoner for behandling av åpent foramen ovale hos hjerneinfarktpasienter.
\end{abstract}

KUNNSKAPSGRUNNLAG Artikkelen er basert på et ikke-systematisert søk i PubMed. Vi vektlegger særlig tre nylig publiserte randomiserte studier.

RESULTATER Transøsofageal ekkokardiografi med saltvannskontrast er gullstandard for å påvise åpent foramen ovale, men fremdeles er det uklart hvem som har nytte av diagnostikk og behandling. Ingen av de tre randomiserte studiene av antitrombotisk behandling versus kateterbasert lukking hos pasienter som har hatt hjerneinfarkt viser forskjell i utfall, men subgruppeanalyser tyder på at lukking hos unge (< 50 år) med store foramen ovale gir færre residivinfarkter. Det pågår ytterligere to randomiserte studier av antitrombotisk behandling alene versus lukking.

FORTOLKNING Hos hjerneinfarktpasienter med åpent foramen ovale er valget mellom livslang antitrombotisk behandling alene eller kateterbasert lukking en vanskelig avveining. Behandling med platehemmere er fortsatt førstevalg i de fleste tilfeller. Flere veldesignede studier er nødvendig for å identifisere hvilke pasienter som vil ha best nytte av lukking.

Antitrombotisk behandling og/eller kateterbasert lukking kan forebygge residiverende cerebrovaskulære episoder hos pasienter med åpent (eller patent) foramen ovale og transitorisk iskemisk anfall (TIA)/embolisk hjerneinfarkt. De norske retningslinjene for kateterbasert lukking er basert på systematiske oversikter (1), og forebyggende behandling praktiseres noe ulikt.

Vi presenterer her en ung pasient med embolisk hjerneinfarkt og åpent foramen ovale. Deretter diskuterer vi diagnostikk og behandling på generelt grunnlag ut fra oppdatert internasjonal litteratur, inkludert nyere resultater fra de første randomiserte studier på feltet: CLOSURE-studien (Closure of patent foramen ovale versus medical therapy after cryptogenic stroke) (2), RESPECT-studien (Randomized evaluation of recurrent stroke comparing PFO closure to established current standard of care treatment) (3) og PC-studien (Clinical trial comparing percutaneous closure of patent foramen ovale using the Amplatzer PFO Occluder with medical treatment in patients with cryptogenic embolism) (4).

\section{Kunnskapsgrunnlag}

Artikkelen er basert på gjennomgang av relevant norsk og engelskspråklig litteratur med utgangspunkt i søk i PubMed. Vi brukte søkeordet «patent foramen ovale» kombinert med hvert av søkeordene «review», «transitory ischemic attack», «stroke», «closure» og «treatment», avgrenset til perioden 1982 til 1.4. 2013.

Originalartikler, oversiktsartikler og kasuistiske meddelelser ble vurdert. Vi har valgt å legge spesiell vekt på resultater fra tre randomiserte studier: CLOSURE, RESPECT og PC.

\section{Kasuistikk}

En mann i 20-årene hadde tilbakevendende migreneanfall med aura, siste gang seks uker før det aktuelle. Han var ikke-røyker og brukte ingen medisiner. Innleggelsesdagen våknet han med migreneliknende hodepine. Tre timer senere, rett etter at han hadde gjort armhevinger, utviklet han nummenhet $\mathrm{i}$ venstre arm, pareser i venstre kroppshalvdel og dysartri. Man mistenkte en vaskulær hendelse i høyre hemisfære.

Cerebral computertomografi (CT) utført ved lokalsykehuset viste «hyperdens høyre a. cerebri media-tegn», og cerebral CTangiografi viste en embolisk okklusjon i delingen av høyre a. cerebri media. Cerebral CT dagen etter dokumenterte infarkt i basalgangliene i høyre hemisfære, og CT-angiografi viste fullstendig rekanalisering av høyre a. cerebri media. Transøsofageal ekkokardiografi med saltvannskontrast to dager etter innleggelsen viste åpent foramen ovale med diameter på $4 \mathrm{~mm}$ (fig 1).

Pasienten ble utskrevet uten sekvele med acetylsalisylsyre $75 \mathrm{mg}$ daglig. Han ble henvist til kardiologisk vurdering med tanke på kateterbasert lukking av åpent foramen ovale.

\section{Patofysiologi}

Åpent foramen ovale er en persisterende føtal forbindelse mellom høyre og venstre atrium som skyldes inkomplett lukking av astrieseptum. Dersom trykket i høyre atrium oversti-

\author{
Mirza Jusufovic \\ mirzajus@hotmail.com \\ Nevrologisk avdeling \\ Klinikk for kirurgi og nevrofag \\ Oslo universitetssykehus, Rikshospitalet \\ Lars Thomassen \\ Nevrologisk avdeling \\ Haukeland universitetssykehus

\section{Mona Skjelland} \\ Nevrologisk avdeling \\ Klinikk for kirurgi og nevrofag \\ Oslo universitetssykehus, Rikshospitalet \\ बL \\ Engelsk oversettelse på www.tidsskriftet.no \\ Video på www.tidsskriftet.no
}

\section{HOVEDBUDSKAP}

Den optimale behandling av pasienter med kryptogent infarkt og åpent foramen ovale er fortsatt uavklart

Behandling med platehemmere er fortsatt førstevalg for flertallet av pasientene dersom de ikke kan delta i en randomisert studie av kateterbasert lukking

Kateterbasert lukking kan være aktuelt for undergrupper av pasienter, de med særlig høy risiko for residivinfarkt 
ger trykket $\mathrm{i}$ venstre atrium, f.eks. ved fysisk anstrengelse eller Valsalva-manøver (5), vil blod shuntes fra høyre til venstre atrium. Åpent foramen ovale er årsak til $95 \%$ av slik høyre-venstre-shunting hos voksne (6).

Emboluser som pga. en intrakardial shunt passerer fra høyre til venstre side klassifiseres som paradokse (7). Paradoks embolisering til hjernen forekommer ved åpent foramen ovale (fig 2) (8).

\section{Forekomst}

Åpent foramen ovale er vanlig i normalbefolkningen. Autopsistudier viser en forekomst på $27,3 \%$ (9). TIA og hjerneinfarkt uten påvisbar årsak klassifiseres som kryptogene. Andelen kryptogene infarkter er lavere blant eldre pasienter og anslås til $40 \%$ i den generelle slagpopulasjonen (10). I en populasjonsbasert studie fra Hordaland fant man kryptogene infarkter hos $50,7 \%$ av alle pasienter under 40 år, på tross av grundig vaskulær utredning (11).

Den tidligere forskningen vedrørende sammenheng mellom åpent foramen ovale og kryptogene infarkter har vist motstridende resultater. For eksempel - en metaanalyse av pasient-kontroll-studier bekreftet at det er en assosiasjon mellom åpent foramen ovale og kryptogene infarkter hos yngre pasienter ( $<55$ år) sammenliknet med kontrollpersoner (oddsratio (OR) 5,0; $95 \%$ konfidensintervall (KI) 3,2-7,7) (12). Denne metaanalysen omfattet studier av ulik størrelse, og ekkokardiografi var utført på ulike indikasjoner. Disse forholdene kan ha påvirket seleksjonen av studiedeltakere, og resultatene må derfor tolkes med forsiktighet.

Motsatt fant man i en pasient-kontrollstudie at åpent foramen ovale ikke var forbundet med økt slagrisiko (OR 1,1; $95 \% \mathrm{KI}$ 0,6-1,9) (13). Imidlertid finnes det flere kasuistiske meddelelser der man har rapportert om cerebrovaskulære episoder og funn av innkilt embolus $\mathrm{i}$ foramen ovale ved ekkokardiografi (14-16).

Trykkfallssyke hos dykkere og migreneanfall med aura synes å ha sammenheng med åpent foramen ovale $(17,18)$. Det er imidlertid nå godt dokumentert at migrene med aura ikke er indikasjon for lukking (19).

Selv om noen studier har vist at stor åpning og/eller koeksisterende atrieseptumaneurisme gir økt slagrisiko $(20,21)$, har man $\mathrm{i}$ andre studier ikke kunnet bekrefte dette $(2,22-24)$.

\section{Utredning}

Transøsofageal ekkokardiografi med saltvannskontrast er gullstandard for diagnostisering for høyre-venstre-shunt $(25,26)$. Med denne undersøkelsen kan åpent foramen ovale visualiseres og shunten diagnostiseres ved påvisning av mikrobobler under Val-

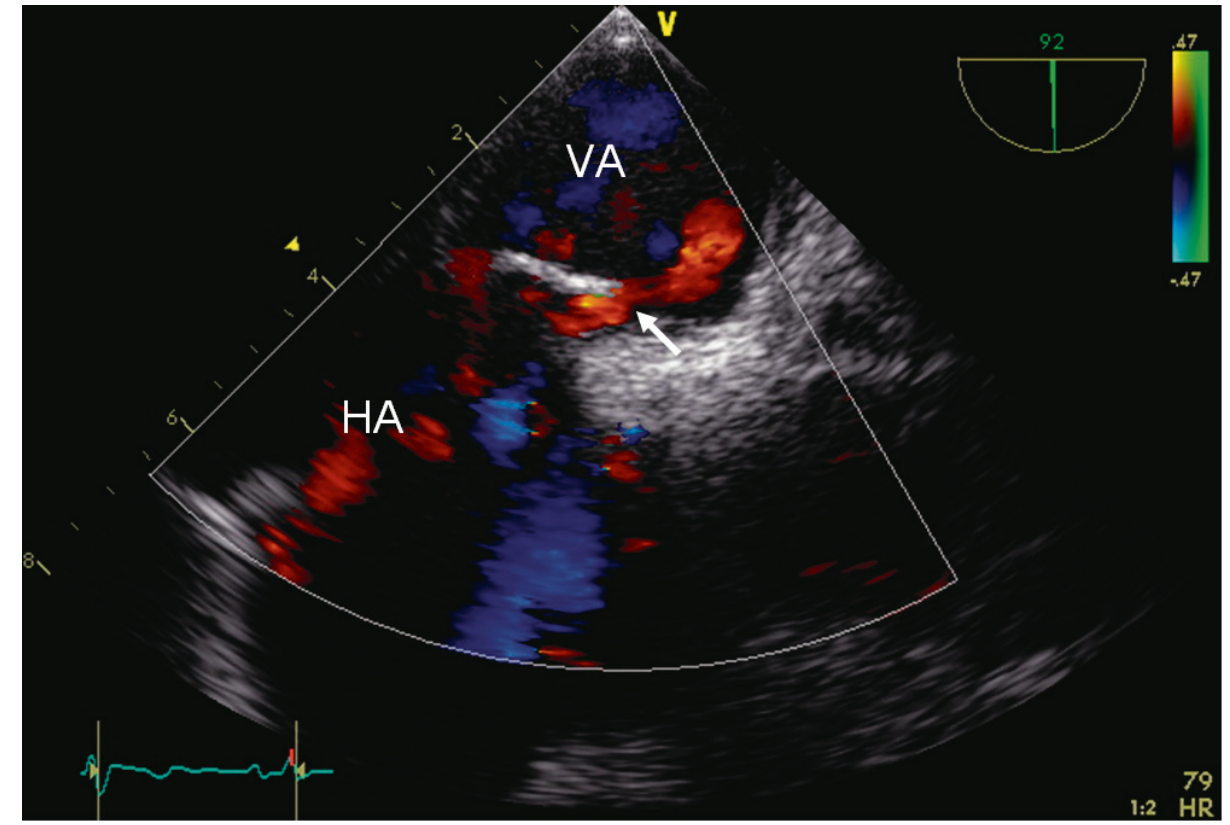

Figur 1 Transøsofageal ekkokardiografi med saltvannskontrast to dager etter innleggelse viser høyre-venstreshunting fra høyre atrium (HA) til venstre atrium (VA) ved Valsalva-manøver, forenlig med åpent foramen ovale (pil). Foto: Hjerteavdelingen, Oslo universitetssykehus, Rikshospitalet

salva-manøver i venstre atrium innen tre til fire hjerteslag etter saltvannsinjeksjon $\mathrm{i}$ en vene $(17,27)$.

I fagmiljøene er det vanlig å anta at det er en etiologisk sammenheng mellom åpent foramen ovale og kryptogene infarkter hos unge pasienter $(<50$ år) med positive funn ved transøsofageal ekkokardiografi og et embolisk, ikke et trombotisk infarkt på cerebral MR og uten andre påviste årsaker til hjerneinfarkt. Andre faktorer som taler for en slik sammenheng er Valsalva-manøver ved symptomdebut, påvist dyp venetrombose og/eller trombofili.

Én studie viste en sensitivitet og en spesifisitet for å detektere åpent foramen ovale på henholdsvis $100 \%$ og $96 \%$ for transøsofageal ekkokardiografi og $94 \%$ og $96 \%$ for transtorakal ekkokardiografi (28). Transøsofageal ekkokardiografi gir mer informasjon om de anatomiske detaljene enn transtorakal ekkokardiografi. Ved transøsofageal ekkokardiografi kan imidlertid Valsalva-manøver være vanskelig grunnet sedasjon og anvendelse av skop, og transtorakal ekkokardiografi kan da være en bedre metode.

En alternativ metode for å påvise høyrevenstre-shunt er transkranial dopplersonografi med intravenøs saltvannskontrast og påvisning av mikrobobler i cerebral sirkulasjon (7). Metoden er mer sensitiv enn transøsofageal ekkokardiografi for å påvise små shunter og er nyttig i primærutredningen. Negativ transkranial dopplersonografi utelukker høyre-venstre-shunt.

D-dimer ved mistanke om dyp venetrombose har høy sensitivitet (90-99\%), men lav spesifisitet (29). I PELVIS-studien (Paradoxical emboli from large veins in ischemic stroke) var det høyere prevalens av bekkenvenetrombose påvist med MR-venografi ved kryptogene infarkter $(20 \%)$ enn ved hjerneinfarkt av kjent etiologi $(4 \%)(p<0,025)(30)$.

Ved kryptogene infarkter anbefaler vi rutinemessig ultralydunders $ø$ kelse av underekstremitetsvener med tanke på dyp venetrombose. Samtidig bør CT- eller MR-venografi utføres for å få oversikt over bekkenvener og v. cava inferior. Testing av risikofaktorer for venøs tromboembolisme inkluderer aktivert protein C-resistens, antitrombin-, protein C- og protein S-mangel, lupusantikoagulant, antikardiolipinantistoff $\mathrm{IgG}$, antikardiolipinantistoff IgM og protrombingenmutasjon.

\section{Behandling}

Ifølge nasjonale anbefalinger bør sekundærprofylakse til pasienter med hjerneinfarkter som antas å skyldes åpent foramen ovale bestå av acetylsalisylsyre og dipyridamol/klopidogrel fremfor antikoagulasjon (26).

Kateterbasert lukking er aktuelt å vurdere ved residiverende hjerneinfarkter der annen sannsynlig årsak ikke kan påvises (26). American Heart Association og American College of Cardiology har samme anbefaling (31). Den vitenskapelige dokumentasjonen er imidlertid mangelfull $(31,32)$.

\section{Medikamentell behandling}

Antitrombotisk behandling består av enten platehemming eller antikoagulasjon. Effekten av acetylsalisylsyre ble belyst i en fransk mul- 

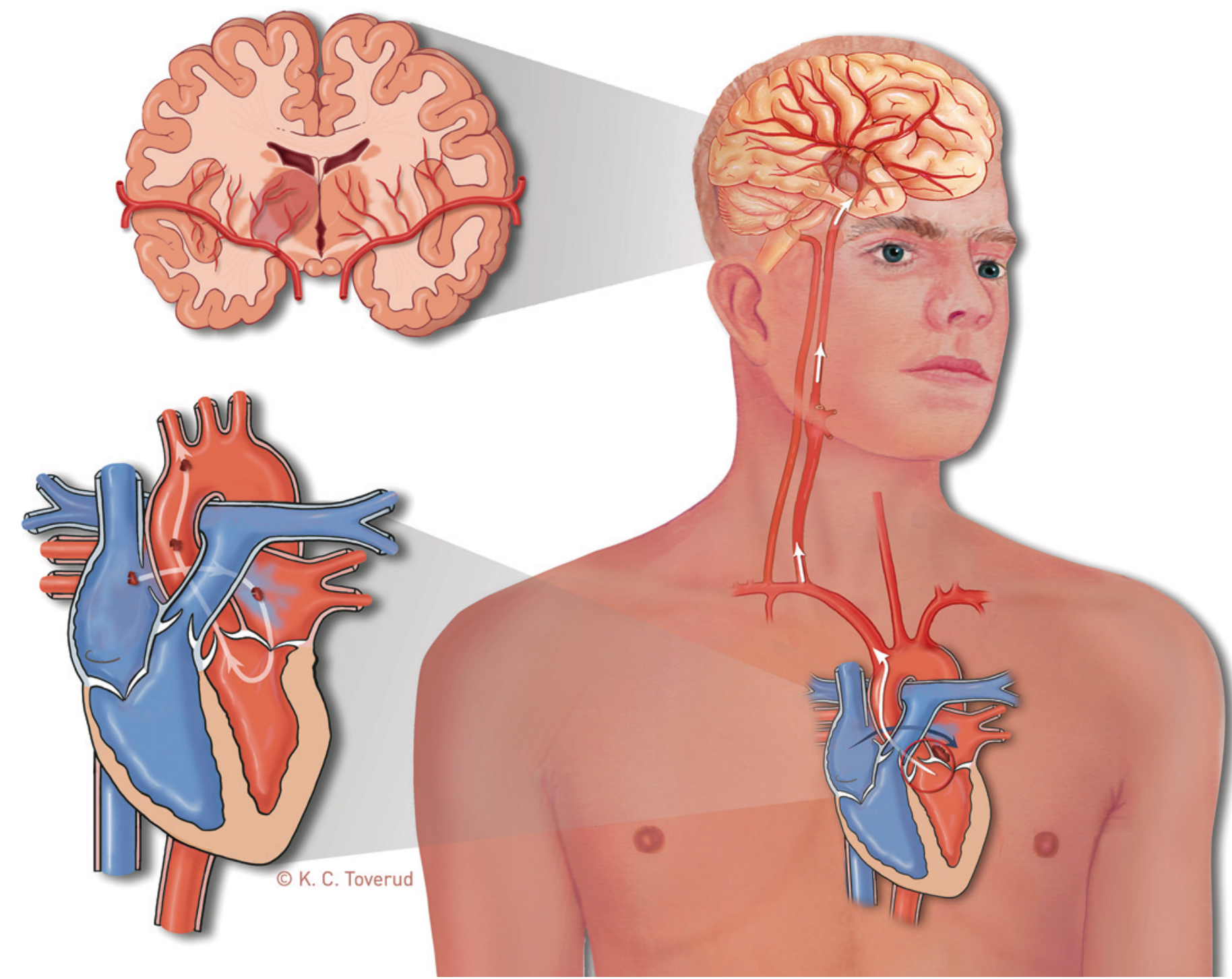

Figur 2 En embolus passerer et åpent foramen ovale fra høyre forkammer til venstre og emboliserer til hjernen, hvor den forårsaker et hjerneinfarkt

tisenterstudie, der man fant lavere insidens av residivinfarkt etter fire års oppfølging hos 216 pasienter med kryptogene infarkter og åpent foramen ovale (risiko 2,3\%; $95 \% \mathrm{KI}$ $0,3-4,3)$ enn hos infarktpasienter uten intrakardial shunt (risiko 4,2\%; $95 \%$ KI 1,8-6,6) (21). Begge grupper fikk acetylsalisylsyre (300 mg daglig) som sekundærprofylakse. Insidensen av residivinfarkt i samme periode var firedoblet hos 51 av pasientene med koeksisterende atrieseptumaneurisme (risiko $15,2 \%$; $95 \%$ KI 1,8-28,6). Studien konkluderte med at warfarin bør vurderes for denne undergruppen.

I PICSS-studien (PFO in cryptogenic stroke study), derimot, der man sammenliknet pasienter uten og med åpent foramen ovale behandlet med acetylsalisylsyre ( 325 mg daglig) eller warfarin (med INR-mål 1,4-2,8) etter gjennomgått hjerneinfarkt (22), var det ingen statistisk signifikant for- skjell mellom behandlingsgruppene i toårsrisiko for residivinfarkt eller død, ei heller for pasientene med koeksisterende atrieseptumaneurisme.

\section{Kirurgisk behandling}

Kirurgisk behandling krever median sternotomi, behandling med hjerte-lunge-maskin, en til to ukers rehabilitering ved sykehus og fire til åtte ukers sykmelding (33). Inngrepet er ikke aktuelt etter at kateterbasert lukking ble introdusert (34).

\section{Kateterbasert lukking}

En systematisk litteraturgjennomgang av 20 studier der man har undersøkt effekten av kateterbasert lukking i forhold til antitrombotisk behandling (35) viste at den årlige risikoen for residiverende TIA eller hjerneinfarkt var lavere $\mathrm{i}$ gruppen med lukking $(1,3 \%$; $95 \%$ KI $1,0-1,8)$ enn hos pasienter som fikk antitrombotisk behandling (5,2\%; $95 \%$ KI 4,4-6,2). Spesielt gjaldt dette pasienter med koeksisterende atrieseptumaneurisme.

Andre studier har ikke vist risikoreduksjon ved lukking sammenliknet med antitrombotisk behandling alene $(2-4,36)$. I en norsk studie med 15 pasienter som fikk utført kateterbasert lukking fant man ingen nye cerebrovaskulære episoder etter en median oppfølgingstid på ni måneder (33).

Det finnes kun tre randomiserte studier som omhandler sekundærprofylakse hos pasienter med TIA eller hjerneinfarkt og åpent foramen ovale - CLOSURE-studien (2), RESPECT-studien (3) og PC-studien (4).

I CLOSURE-studien ble 909 pasienter i aldersgruppen 18-60 år randomisert (2). Det var ikke signifikant forskjell $\mathrm{i}$ insidensen av det primære endepunkt, som var kombinasjon av residivinfarkt, TIA eller død, etter to 
år. Insidensen var henholdsvis 5,5\% hos pasienter med lukking $(\mathrm{n}=447)$ og $6,8 \%$ hos pasienter som fikk antitrombotisk behandling $(n=462)(p=0,37)$. I begge grupper var toårsrisikoen for å få hjerneinfarkt lavere enn antatt (nesten $3 \%$ ) og skyldtes i $81 \%$ av tilfellene annen etiologi enn åpent foramen ovale. Derimot var omfanget av TIA $(3,1 \%$ respektive $4,1 \%$ ) høyere enn antatt. Resultatene kan indikere at den forste cerebrovaskulære episoden ikke skyldtes åpent foramen ovale og at den bakenforliggende årsaken kan ha blitt oversett.

De vanligste komplikasjoner ved kateterbasert lukking er dislosering av lukningsenheten, lyskehematom, arteriovenøs fistel, trombedanning på lukningsenheten, lungeembolisme, blødning, arytmi og hjertetamponade (1). I CLOSURE-studien økte kateterbehandling den absolutte risikoen for alvorlige vaskulære hendelser med 3,2 \% og induserte atrieflimmer hos 5,7\%. Én innvending mot de høye komplikasjonstallene har vært at flere av de involverte behandlingssentrene hadde for lite trening og rutine på kateterteknikken. Ingen døde av nevrologiske årsaker i løpet av oppfølgingen.

CLOSURE-studien gir ikke holdepunkter for å anta at det blir færre residivinfarkter etter kateterbasert lukking av åpent foramen ovale enn etter antitrombotisk behandling alene. Subgruppeanalyser viste tilsvarende resultater ved store åpninger med atrieseptumaneurisme.

CLOSURE-studien har en rekke svakheter, blant annet lav inklusjonsrate. Det tok fem år å rekruttere 909 pasienter, og gjennomsnittlig rekruttering per senter var to pasienter $\mathrm{i}$ året (37). I tillegg ble det inkludert pasienter med en rekke andre risikofaktorer for hjerneslag, bl.a. alder opptil 60 år, hypertensjon, diabetes, aterosklerose og røyking, som alle kan representere systematiske feil. Ikke alle pasienter ble utredet med cerebral MR.

Den medikamentelle behandlingen var heterogen, enten warfarin i 24 måneder eller acetylsalisylsyre eller en kombinasjon av disse. Pasientene i gruppen med lukking skulle ifølge protokollen bruke platehemming, men 97 pasienter brukte warfarin på forhånd. Man benyttet en STARFlex lukningsenhet (NMT Medical) som ikke lenger er tilgjengelig på markedet (38).

I RESPECT-studien ble 980 pasienter i aldersgruppen 18-60 år randomisert og fulgt i 2,5 år (3). Det primære endepunktet var residivinfarkt eller død. Det var ingen signifikant forskjell mellom gruppene. Risikoen for residivinfarkt/død var 0,66 hendelser/100 pasientår i gruppen med lukking og 1,38 i gruppen med antitrombotisk behandling $(p=0,08)$. Subgruppeanalyser viste signifikant forskjell i favør av lukking ved stor åpning $(\mathrm{p}=0,01)$ og koeksisterende atrie- septumaneurisme $(\mathrm{p}=0,02)$. Studien viste at utvalgte pasienter med embolisk infarkt på MR-undersøkelse, uten vaskulære risikofaktorer og med stor åpning kan ha nytte av lukking.

I PC-studien ble 414 pasienter inkludert over fire år (4). Det var ikke noen signifikant forskjell $\mathrm{i}$ insidens av det primære endepunkt, en kombinasjon av residivinfarkt, TIA eller død, etter lukking sammenliknet med antitrombotisk behandling. Det primære endepunkt forekom hos 3,4\% i gruppen med lukking og hos 5,2\% av dem som fikk antitrombotisk behandling $(\mathrm{p}=0,34)$. Det oppsto hjerneinfarkt hos én pasient $(0,5 \%)$ i gruppen med lukking og hos fem pasienter $(2,4 \%)$ i gruppen med antitrombotisk behandling $(\mathrm{p}=0,14)$. Subgruppeanalyser viste en ikke-signifikant forskjell $i$ favør av lukking ved alder $<45$ år og koeksisterende atrieseptumaneurisme.

I både RESPECT- og PC-studien benyttet man AMPLATZER PFO Occluder (St. Jude Medical). Andelen av komplikasjoner var lavere enn i studier der man har brukt STARFlex lukningsenhet, noe som indikerer en bedre sikkerhetsprofil. Insidensen av atrieflimmer ved kateterteknikk var også lavere i RESPECT-studien (3,0\%) og i PC-studien $(2,9 \%)$ sammenliknet med insidensen $\mathrm{i}$ CLOSURE-studien $(5,7 \%)$.

\section{Svakheter ved studiene av kateterbasert lukking}

Vi mener svakhetene er mange. Relevante forskjeller for undergrupper kan være vanskelig å få frem. Det er også grunn til å være kritisk til inklusjonskriteriene - pasienter med tendens til tromboemboliske tilstander er ekskludert, samtidig som man har inkludert pasienter med andre kjente risikofaktorer for hjerneinfarkt.

Det er unge pasienter med risikofaktorer for venøs tromboembolisme, men uten andre kjente risikofaktorer, som har best forventet lukkingseffekt og derfor primært bør inkluderes i slike studier. Dessuten trengs det lengre oppfølgingstid (> 2 år) og en stor studiepopulasjon for å kunne demonstrere signifikant reduksjon i risikoen for residivinfarkter med lukking.

Videre bør det være en forutsetning at lukkingsprosedyren gjøres på sykehus med tilstrekkelig erfaring og lav komplikasjonsrate.

Det pågår to randomiserte studier (REDUCE og CLOSE) av kateterbasert lukking versus antitrombotisk behandling. Nevrologisk avdeling og Hjerteavdelingen ved Oslo universitetssykehus, Rikshospitalet, og Haukeland universitetssykehus deltar i REDUCE-studien. Resultatene fra disse studiene kan forhåpentligvis gi oss bedre dokumentasjon, slik at vi kan velge den beste behandlingen for den enkelte pasient.

\section{Konklusjon}

Diagnostikk av åpent foramen ovale hos pasienter med kryptogent infarkt bør innbefatte transøsofageal ekkokardiografi med saltvannskontrast, ultralydundersøkelse og CT- eller MR-venografi av underekstremitetsvener med tanke på dyp venetrombose samt testing av risikofaktorer for venøs tromboembolisme. Hjerneinfarktet må være embolisk og bekreftet på MR-undersøkelse.

Norske retningslinjer presiserer at resultater fra pågående randomiserte studier vil avgjøre hvilken plass lukking bør få i sekundærforebyggingen. Ferske randomiserte studier indikerer at antitrombotisk behandling er like bra som kateterlukking. Det er grunn til å tro at undergrupper av pasientene, som unge ( $<50$ år) med trombofili, store defekter eller aneurismer, kan ha nytte av lukking, men resultatene fra de randomiserte studiene er ikke entydige. Lukking av åpent foramen ovale bør derfor i hovedsak gjøres som ledd i randomiserte studier slik at fremtidige anbefalinger kan bli bedre vitenskapelig dokumentert.

Pasienten har gitt samtykke til at artikkelen blir publisert.

\section{Mirza Jusufovic (f. 1980)}

er assistentlege og har cerebrovaskulær sykdom som hovedinteresse.

Forfatter har fylt ut ICMJE-skjemaet og oppgir ingen interessekonflikter.

\section{Lars Thomassen (f. 1947)}

er spesialist i nevrologi, med spesialkompetanse i nevrovaskulære sykdommer. Han er professor ved Universitetet i Bergen og leder Nevrovaskulær forskningsgruppe.

Forfatter har fylt ut ICMJE-skjemaet og oppgir følgende interessekonflikter: Han har fått studiebidrag og er medlem av den vitenskapelige rådgivningsgruppen for REDUCE-studien.

\section{Mona Skjelland (f 1956)}

er spesialist i nevrologi og overlege. Forfatter har fylt ut ICMJE-skjemaet og oppgir følgende interessekonflikter: Hun har fått studiebidrag og reisest $\varnothing$ tte i forbindelse med REDUCE-studien.

\footnotetext{
Litteratur

1. Khairy P, O'Donnell CP, Landzberg MJ. Transcatheter closure versus medical therapy of patent foramen ovale and presumed paradoxical throm boemboli: a systematic review. Ann Intern Med 2003; 139: 753-60

2. Furlan AJ, Reisman M, Massaro J et al. Closure or medical therapy for cryptogenic stroke with patent foramen ovale. N Engl J Med 2012; 366: 991 -9.

3. Carroll JD, Saver JL, Thaler DE et al. Closure of patent foramen ovale versus medical therapy after cryptogenic stroke. N Engl J Med 2013; 368: $1092-100$. 
4. Meier B, Kalesan B, Mattle HP et al. Percutaneous closure of patent foramen ovale in cryptogenic embolism. N Engl J Med 2013: 368: 1083-91.

5. Georgopoulos SE, Chronopoulos A, Dervisis KI et al. Paradoxical embolism. An old but, paradoxically, under-estimated problem. J Cardiovasc Surg (Torino) 2001; 42: 675-7.

6. Meier B, Frank B, Wahl A et al. Secondary stroke prevention: patent foramen ovale, aortic plaque, and carotid stenosis. Eur Heart J 2012; 33: 705-13. 713a, 713b.

7. Thomassen L, Waje-Andreassen U, Næss $\mathrm{H}$ et al. Transkranial dopplersonografi, paradokse embolier og høyre-venstre-shunt. Tidsskr Nor Lægeforen 2003; 123: 789-90.

8. Lamy C, Giannesini C. Zuber M et al. Clinical and imaging findings in cryptogenic stroke patients with and without patent foramen ovale: the PFOASA Study. Atrial Septal Aneurysm. Stroke 2002; 33: $706-11$.

9. Hagen PT, Scholz DG, Edwards WD. Incidence and size of patent foramen ovale during the first 10 decades of life: an autopsy study of 965 normal hearts. Mayo Clin Proc 1984; 59: 17-20.

10. Sacco RL, Ellenberg JH, Mohr JP et al. Infarcts of undetermined cause: the NINCDS Stroke Data Bank. Ann Neurol 1989; 25: 382-90.

11. Næss H. Hjerneinfarkt hos unge voksne. Tidsskr Nor Lægeforen 2007; 127: 751-3.

12. Overell JR, Bone I, Lees KR. Interatrial septal abnormalities and stroke: a meta-analysis of case-control studies. Neurology 2000; 55: 1172-9.

13. Petty GW, Khandheria BK, Meissner I et al. Population-based study of the relationship between patent foramen ovale and cerebrovascular ischemic events. Mayo Clin Proc 2006; 81: 602-8.

14. Augusseau MP, Pacouret G, Charbonnier B et al. Embolie paradoxale et thrombus enclavé dans le foramen ovale. Intérêt de l'échographie transoesophagienne. Arch Mal Coeur Vaiss 1997; 90: 1533-8.

15. Claver E, Larrousse E, Bernal E et al. Giant thrombus trapped in foramen ovale with pulmonary embolus and stroke. J Am Soc Echocardiogr 2004; 17: $916-8$.

16. Aggarwal K, Jayam VK, Meyer MA et al. Thrombusin-transit and paradoxical embolism. J Am Soc Echocardiogr 2002; 15: 1021-2.

17. Sivertsen W, Risberg J, Norgård G. Apent foramen ovale og trykkfallssyke hos dykkere. Tidsskr Nor Legeforen 2010; 130: 834-8.
18. Schwedt TJ, Demaerschalk BM, Dodick DW Patent foramen ovale and migraine: a quantitative systematic review. Cephalalgia 2008; 28: $531-40$.

19. Dowson A, Mullen MJ, Peatfield R et al. Migraine Intervention With STARFlex Technology (MIST) trial: a prospective, multicenter, double-blind, sham-controlled trial to evaluate the effectiveness of patent foramen ovale closure with STARFlex septal repair implant to resolve refractory migraine headache. Circulation 2008; 117 : 1397-404.

20. Cabanes L, Mas JL, Cohen A et al. Atrial septal aneurysm and patent foramen ovale as risk factors for cryptogenic stroke in patients less than 55 years of age. A study using transesophageal echocardiography. Stroke 1993; 24: 1865-73.

21. Mas JL, Arquizan C, Lamy C et al. Recurrent cerebrovascular events associated with patent foramen ovale, atrial septal aneurysm, or both. N Engl J Med 2001; 345: 1740-6.

22. Bogousslavsky J, Garazi S, Jeanrenaud X et al. Stroke recurrence in patients with patent foramen ovale: the Lausanne Study. Neurology 1996; 46 : $1301-5$.

23. Homma S, Sacco RL, Di Tullio MR et al. Effect of medical treatment in stroke patients with patent foramen ovale: patent foramen ovale in Cryptogenic Stroke Study. Circulation 2002; 105: 2625-31.

24. Steiner MM, Di Tullio MR, Rundek T et al. Patent foramen ovale size and embolic brain imaging findings among patients with ischemic stroke. Stroke 1998; 29: 944-8.

25. Friis P, Gjestvang FT, Fausa D et al. Trombotisk eller embolisk hjerneslag? Tidsskr Nor Lægeforen 2001: 121: 2143-6.

26. Indredavik B, Salvesen R, Næss $\mathrm{H}$ et al. red Nasjonal retningslinje for behandling og rehabilitering ved hjerneslag. Oslo: Helsedirektoratet, 2010.

27. Attaran RR, Ata I, Kudithipudi V et al. Protocol for optimal detection and exclusion of a patent foramen ovale using transthoracic echocardiography with agitated saline microbubbles. Echocardiography 2006; 23: 616-22.

28. Kerr AJ, Buck T, Chia K et al. Transmitral Doppler: a new transthoracic contrast method for patent foramen ovale detection and quantification. J Am Coll Cardiol 2000; 36: 1959-66.

29. Freyburger $\mathrm{G}$, Trillaud $\mathrm{H}$, Labrouche $\mathrm{S}$ et al. $\mathrm{D}$-dimer strategy in thrombosis exclusion-a gold standard study in 100 patients suspected of deep venous thrombosis or pulmonary embolism: $8 \mathrm{DD}$ methods compared. Thromb Haemost 1998; 79: 32-7.

30. Cramer SC, Rordorf G, Maki JH et al. Increased pelvic vein thrombi in cryptogenic stroke: results of the Paradoxical Emboli from Large Veins in Ischemic Stroke (PELVIS) study. Stroke 2004; 35 : 46-50.

31. Furie KL, Kasner SE, Adams RJ et al. Guidelines for the prevention of stroke in patients with stroke or transient ischemic attack: a guideline for healthcare professionals from the american heart association/american stroke association. Stroke 2011; 42: 227-76.

32. Kitsios GD, Dahabreh IJ. Abu Dabrh AM et al. Patent foramen ovale closure and medical treatments for secondary stroke prevention: a systematic review of observational and randomized evidence. Stroke 2012; 43: 422-31.

33. Hirth A, Greve G, Rosland GA et al. Kateterbasert lukking av åpentstående foramen ovale hos unge slagpasienter. Tidsskr Nor Lægeforen 2003; 123 : $785-8$.

34. Bridges ND, Hellenbrand W, Latson L et al. Transcatheter closure of patent foramen ovale after presumed paradoxical embolism. Circulation 1992; 86: 1902-8.

35. Wöhrle J. Closure of patent foramen ovale after cryptogenic stroke. Lancet 2006: 368: $350-2$.

36. Harrer JU, Wessels T, Franke A et al. Stroke recurrence and its prevention in patients with patent foramen ovale. Can J Neurol Sci 2006; 33 $39-47$.

37. Johnston SC. Patent foramen ovale closure closing the door except for trials. N Engl J Med 2012; 366: 1048-50

38. Krumsdorf U, Ostermayer S, Billinger $\mathrm{K}$ et al. Incidence and clinical course of thrombus formation on atrial septal defect and patient foramen ovale closure devices in 1,000 consecutive patients. J Am Coll Cardiol 2004; 43: 302-9.

Mottatt 11.1. 2013, første revisjon innsendt 26.4 . 2013, godkjent 14.10. 2013. Redaktør: Vegard Bruun Wyller. 